\title{
APLIKASI METODE GOAL PROGRAMMING PADA PERENCANAAN PRODUKSI KLAPPERTAART PADA USAHA KECIL MENENGAH (UKM) NAJMAH KLAPPERTAART
}

\author{
D. Sutrisno ${ }^{1}$, A. Sahari², D. Lusiyanti ${ }^{3}$ \\ 1,2,3Program Studi Matematika Jurusan Matematika FMIPA Universitas Tadulako \\ Jalan Soekarno-Hatta Km. 09 Tondo, Palu 94118, Indonesia. \\ 1sutrisnodedy05@gmail.com, 2agus_sh@yahoo.com,33desylusiyanti@gmail.com
}

\begin{abstract}
Production planning is important in the management of the company. Preparation of production planning needs to consider the optimization of production at minimum cost. Goal Programming method is one method that can be used to optimize production planning. Najmah Klappertaart UKMs is one of the home industry in the city of Palu, Central Sulawesi engaged in food. The purpose of this study is to optimize the amount of production klappertaart and minimizing production costs Klappertaart using Goal Programming method with the help of application WINQSB. WinQSB application is an interactive system to help make decisions that are useful to solve different kinds of problems in the field of operations research. Based on the research results, obtained optimal value klapertart sales profit revenue of Rp. 2.338.862 increased by Rp. 158.179 of revenue the previous profit ofRp. 2.180.683. While the value of the production cost minimization klappertaart Rp. 1.299 .998 decreased by Rp. 38.210 from the previous production costs Rp.1.329.316, with total production of as much as 333 klappertaart packaging/day increased from the previous production of 309 packaging/day.
\end{abstract}

Keywords : Application WINQSB, Goal Programming, Klappertaart, Production Planning

\section{ABSTRAK}

Perencanaan produksi merupakan hal penting dalam manajemen perusahaan. Penyusunan perencanaan produksi perlu mempertimbangkan optimasi produksi dengan biaya yang minimum. Metode Goal Programming merupakan salah satu metode yang dapat digunakan dalam mengoptimalkan perencanaan produksi. UKM Najmah Klappertaart merupakan salah satu industri rumahan di Kota Palu Sulawesi Tengah yang bergerak dibidang makanan. Tujuan penelitian ini adalah mengoptimalkan jumlah produksi Klappertaart dan meminimalkan biaya produksi klappertaart menggunakan metode Goal Programming dengan bantuan aplikasi WINQSB. Aplikasi WinQSB adalah sistem interaktif untuk membantu pengambilan keputusan yang berguna untuk memecahkan berbagai jenis masalah dalam bidang riset operasi. Berdasarkan hasil penelitian, diperoleh nilai optimal pendapatan laba penjualan klappertaart sebesarRp. 2.338 .862 meningkat sebesar Rp. 158.179 dari pendapatan laba sebelumnya yaitu Rp. 2.180.683. Sedangkan nilai minimasi biaya produksi klappertaart sebesar Rp. 1.299.998 menurun sebesar Rp. 29.318 dari biaya produksi sebelumnya yaitu Rp.1.329.316, dengan jumlah produksi klappertaart sebanyak 333 kemasan/hari meningkat dari produksi sebelumnya sebanyak 309 kemasan/hari.

Kata Kunci : : Aplikasi WINQSB, Goal Programming, Klappertaart, Perencanaan Produksi. 


\section{PENDAHULAN}

\subsection{Latar Belakang}

Seiring dengan berkembangnya jaman dan pesatnya ilmu pengetahuan, perusahaan yang menawarkan produk juga semakin banyak. Setiap perusahaan berusaha mempromosikan produknya sebaik mungkin dan menarik banyak peminat serta dapat menguasai pasar. Menurut Harini (2014), Perencanaan produksi adalah aktivitas untuk menetapkan produk yang diproduksi, jumlah yang dibutuhkan, kapan produk tersebut harus selesai dan sumber-sumber yang dibutuhkan. Dalam penyusunan perencanaan produksi, hal yang perlu dipertimbangkan adalah adanya optimasi produksi sehingga akan dapat dicapai tingkat biaya yang paling rendah untuk pelaksanaan proses produksi tersebut.

Perancanaan produksi dengan menggunakan metode Goal Programming merupakan salah satu metode yang dapat mengoptimalkan perancanaan produksi.Goal Programming merupakan perluasan dari model linear programming, sehingga seluruh asumsi, notasi, formulasi model matematis, prosedur perumusan model dan penyelesaiannya tidak berbeda. Oleh karena itu, konsep dasar pemrograman linear akan selalu melandasi pembahasan model Goal Programming.Usaha Kecil Menengah (UKM) Najmah Klappertaart merupakan salah satu UKM rumahan yang bergerak dalam produksi dan penjualan makanan yang berada di Kota Palu Sulawesi Tengah. Adapun hasil produksinya yaitu Klappertaart. Klappertaart yang diproduksi oleh Najmah Klappertarat terdiri dari 2 jenis Klappertaart, yaitu Klappetaart basah dan Klappertarrt kering.

Berdasarkan uraian diatas maka penulis tertarik untuk melakukan penelitian dengan mengangkat judul "Aplikasi Metode Goal Programming Pada Perencanaan Produksi Klappertaart".

\subsection{RumusanMasalah}

Berdasarkan latar belakang yang di uraikan diatas maka permasalahan dari penelitian ini adalah :

1. Bagaimana menentukan jumlah produk yang optimal menggunakan metode Goal Programming sehingga didapatkan laba yang maksimal?

2. Berapa minimal biaya produksi yang dikeluarkan oleh Najmah Klappertaart dengan menggunakan metode Goal Programming? 


\subsection{Tujuan Penelitian}

Tujuan penelitian ini adalah :

1. Memperoleh jumlah produksi yang optimal sehingga mendapatkan laba maksimal dari pendapatan laba sebelumnya dengan menggunakan metode Goal Programming.

2. Memperoleh biaya produksi yang minimum dengan menggunakan metode Goal Programming.

\subsection{Manfaat Penelitian}

Penelitian ini di harapkan dapat memperoleh manfaat sebagai berikut :

1. Dengan menggunakan metode Goal Programming, dapat diketahui jumlah optimal produk yang dihasilkan.

2. Dapat menghemat atau meminimalkan biaya produksi Klappertaart.

\subsection{Batasan Masalah}

Adapun batasan masalah dari penelitian ini adalah :

1. Produk penelitian merupakan jenis produk yang dihasilkan dari UKM Najmah Klappertaart.

2. Data yang digunakan dalam penelitian ini adalah data satu kali tahapan proses produksi.

\subsection{Asumsi Penelitian}

Data mengenai biaya produksi dan harga penjualan diasumsikan tetap selama penelitian berlangsung. Najmah Klappertaart tidak menginginkan adanya produk yang tidak diproduksi. Minimal dalam sehari Najmah Klappertaart memproduksi paling sedikit 50 kemasan/hari untuk jenis Klappertaart basah dan 5 kemasan/hari untuk Klappertaart kering.

\section{METODE PENELITIAN}

\subsection{Prosedur Penelitian}

1. Mulai penelitian

2. Pengambilan data

3. Perumusan masalah Goal Programming

4. Menentukan variabel keputusan $\left(\mathrm{x}_{\mathrm{j}}\right)$

5. Membuat fungsi kendala

6. Menyatakan fungsi tujuan/sasaran yang ingin dicapai

7. Memformulasikan model Goal Programming

8. Menyelesaikan dengan model optimasi Goal Programming.

9. Menyimpulkan hasil penelitian 


\subsection{Perumumusan Masalah Goal Programming}

Menurut Marpaung J. (2009) bahwa ada beberapa langkah yang harus dilakukan dalam perumusan masalah Goal Programming antara lain :

1. Penentuan variabel keputusan

2. Penentuan fungsi tujuan. Ada 3 macam kemungkinan hubungan tersebut, yaitu $\mathrm{f}_{\mathrm{i}}\left(\mathrm{x}_{\mathrm{i}}\right)=\mathrm{b}_{\mathrm{i}}, \mathrm{f}_{\mathrm{i}}\left(\mathrm{x}_{\mathrm{i}}\right) \geq \mathrm{b}_{\mathrm{i}}$ dan atau $\mathrm{f}_{\mathrm{i}}\left(\mathrm{x}_{\mathrm{i}}\right) \leq \mathrm{b}_{\mathrm{i}}$.

3. Perumusan fungsi sasaran. Pada langkah ini tiap tujuan pada sisi kirinya ditambahkan dengan variabel simpangan $\mathrm{f}_{\mathrm{i}}(\mathrm{x})+\mathrm{d}_{\mathrm{i}}{ }^{-}-\mathrm{d}_{\mathrm{i}}{ }^{+}=\mathrm{b}_{\mathrm{i}}$

4. Penentuan prioritas utama.

- Keinginan dari pengambil keputusan.

- Keterbatasan sumber-sumber yang ada.

5. Penentuan fungsi pencapaian. Dalam memformulasikan fungsi pencapaian adalah menggabungkan Setiap tujuan yang berbentuk minimasi variabel simpangan sesuai dengan prioritasnya.

6. Tentukan nilai non negatif.

7. Penyelesaian model Goal Programming.

Menurut Siswanto (2007), bentuk umum model matematis Goal Programming dapat dirumuskan sebagai berikut.

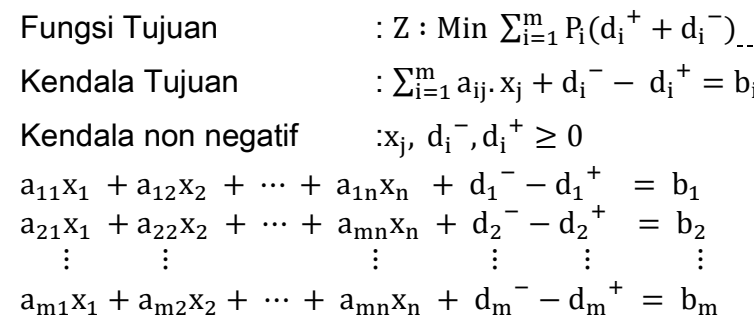

Keterangan :

$Z$ = Fungsi Tujuan

$\mathrm{P}_{\mathrm{i}}=$ Prioritas ke I

$\mathrm{d}_{\mathrm{i}}{ }^{-}=$Variabel deviasi dibawah target $\left(\mathrm{b}_{\mathrm{i}}\right)$

$\mathrm{d}_{\mathrm{i}}{ }^{+}=$Variabel deviasi diatas target $\left(\mathrm{b}_{\mathrm{i}}\right)$

$$
\begin{aligned}
& a_{i j}=\text { Koefisien fungsi kendala tujuan } \\
& x_{j}=\text { Variabel pengambilan keputusan } \\
& b_{i}=\text { Tujuan atau target yang ingin dicapai }
\end{aligned}
$$

\section{HASIL DAN PEMBAHASAN}

\subsection{Hasil}

\subsubsection{Pengumpulan Data}

Najmah Klappertaart memproduksi 7 varian rasa klappertaart. Dimana dari ke-7 klappertaart tersebut terdapat 2 jenis klappertaart yaitu basah dan kering. Untuk klappertaart basah, ukuran kemasan sebuah klappertaart yaitu sebesar $100 \mathrm{gr}$, dengan varian rasa yaitu 
keju, durian, oreo dan original. Sedangkan jenis klappertaart kering, ukuran kemasan sebuah klappertaart yaitu sebesar $450 \mathrm{gr}$ dengan varian rasa yaitu keju, kismis dan original. Berikut tabel produksi klappertaart dari UKM Najmah Klappertaart.

Tabel 1 : Produksi Klappertaart

\begin{tabular}{|c|c|c|c|c|c|c|}
\hline No & $\begin{array}{c}\text { Jenis } \\
\text { Klappertaart }\end{array}$ & $\begin{array}{c}\text { Kemasan/hari } \\
\text { (Buah) }\end{array}$ & $\begin{array}{c}\text { Berat } \\
\text { Kemasan } \\
\text { (gr) }\end{array}$ & $\begin{array}{c}\text { Harga } \\
\text { Jual/Kemasan } \\
\text { (Rp) }\end{array}$ & $\begin{array}{c}\text { Kemasan Dikali } \\
\text { harga } \\
\text { Jual/Kemasan } \\
(R p)\end{array}$ & $\begin{array}{c}\text { Total } \\
\text { Keuntungan/ } \\
\text { hari (Rp) }\end{array}$ \\
\hline 1 & BasahKeju & 72 & 100 & 10,000 & 720,000 & \multirow{7}{*}{$\begin{array}{c}\mathrm{Rp} \\
3,510,000\end{array}$} \\
\hline 2 & Basah durian & 72 & 100 & 10,000 & 720,000 & \\
\hline 3 & Basah Durian & 72 & 100 & 10,000 & 720,000 & \\
\hline 4 & Basah Original & 72 & 100 & 10,000 & 720,000 & \\
\hline 5 & KeringKeju & 7 & 450 & 30,000 & 210,000 & \\
\hline 6 & Keringkismis & 7 & 450 & 30,000 & 210,000 & \\
\hline 7 & Kering Original & 7 & 450 & 30,000 & 210,000 & \\
\hline
\end{tabular}

Sumber : Najmah Klappertarrt

\subsubsection{Pemakaian bahan baku}

Berikut ini merupakan tabel pemakaian bahan baku perkemasan untuk memproduksi klappertaart dalam sehari.

Tabel 2 : Pemakaian bahan baku untuk 1 kali produksi

\begin{tabular}{|c|c|c|c|c|c|c|c|c|}
\hline \multirow{2}{*}{ No } & \multirow{2}{*}{$\begin{array}{c}\text { Bahan baku } \\
\text { (gr) }\end{array}$} & \multicolumn{4}{|c|}{ Klappertaart basah } & \multicolumn{3}{|c|}{ Klappertaart kering } \\
\hline & & Keju & Durian & $\begin{array}{c}\text { Coklat } \\
\text { Oreo }\end{array}$ & Original & Keju & Kismis & Original \\
\hline 1 & Tepung terigu & 8.33 & 8.33 & 8.33 & 8.33 & 42.86 & 42.86 & 42.86 \\
\hline 2 & Susu & 8.33 & 8.33 & 8.33 & 8.33 & 42.86 & 42.86 & 42.86 \\
\hline 3 & Kelapa Muda & 22.22 & 22.22 & 22.22 & 22.22 & 114.29 & 114.29 & 114.29 \\
\hline 4 & Telur & 5.33 & 5.33 & 5.33 & 5.33 & 27.43 & 27.43 & 27.43 \\
\hline 5 & Mentega & 8.33 & 8.33 & 8.33 & 8.33 & 42.86 & 42.86 & 42.86 \\
\hline 6 & Gula pasir & 19.44 & 19.44 & 19.44 & 19.44 & 100 & 100 & 100 \\
\hline 7 & Garam & 0.42 & 0.42 & 0.42 & 0.42 & 2.14 & 2.14 & 2.14 \\
\hline 8 & Vanili & 0.17 & 0.17 & 0.17 & 0.17 & 0.86 & 0.86 & 0.86 \\
\hline 9 & $\begin{array}{l}\text { Tepung } \\
\text { Maizena }\end{array}$ & 12.50 & 12.50 & 12.50 & 12.50 & 64.29 & 64.29 & 64.29 \\
\hline 10 & Keju & 2.50 & - & - & - & 12.86 & - & - \\
\hline 11 & Durian & - & 11.11 & - & - & - & - & - \\
\hline 12 & Coklat Oreo & - & - & 2.44 & - & - & - & - \\
\hline
\end{tabular}




\begin{tabular}{|c|l|c|c|c|c|c|c|c|}
\hline 13 & Kismis & - & - & - & 2.78 & - & 14.29 & 14.29 \\
\hline 14 & Kenari & - & - & - & 2.78 & - & - & 14.29 \\
\hline 15 & $\begin{array}{l}\text { Kayu Manis } \\
\text { (gr) }\end{array}$ & - & - & - & 1.39 & - & - & 7.14 \\
\hline
\end{tabular}

\subsubsection{Perhitungan biaya tenaga kerja}

Biaya tenaga kerja yang dikeluarkan oleh Najmah Klappertaart untuk ke-5 karyawannya yaitu sebesarRp. 4.000 .000 dalam satu bulan kerja. Dimana untuk satu bulan kerja yaitu sebanyak 26 hari. Untuk menghitung biaya tenaga kerja perhari digunakan rumus perhitungan sebagai berikut:

Biaya tenaga kerja/hari $\quad=\frac{\text { Gaji/bulan }}{1 \text { bulan kerja (hari) }}$

dengan menggunakan persamaan (3), diperoleh biaya tenaga kerja/hari yaitu sebesar Rp. 153.846. Selanjutnya akan di hitung berapa biaya tenaga kerja/produk. Untuk menghitung biaya tenaga kerja/produk, digunakan rumus perhitungan sebagai berikut:

Biaya tenaga kerja/produk $=\frac{\text { Biaya tenaga kerja/hari }}{\text { Jumlah varian rasa Klappertaart }}$

Sehigga diperoleh biaya tenaga kerja/perproduk yaitu sebesar Rp. 21.978. selanjutnya akan di hitung berapa biaya tenaga kerja/kemasan. Rumus yang digunakan adalah sebagai berikut :

Biaya tenaga kerja $/$ kemasan $=\frac{\text { Biaya tenaga kerja/produk }}{\text { Jumlah produksi klappertaart } / \text { hari }-}$

dengan menggunakan persamaan (5), diperoleh hasil untuk biaya tenaga kerja/kemasan untuk semua jenis klappertaart basah sebesar Rp. 305. Sedangkan untuk semua jenis klappertaart kering yaitu sebesar Rp. 3.139.

\subsubsection{Perhitungan Biaya Bahan Baku}

Biaya bahan baku yang dihitung yaitu berdasarkan banyaknya pemakaian bahan baku yang digunakan dalam sehari. Untuk perhitungan semua biaya bahan baku yang terpakai digunakan rumus berikut :

Biaya bahan baku $=\frac{\text { kebutuhan } / \text { hari }(g r)}{\text { takaran kemasan bahan baku (gr) }} \times$ harga kemasan bahan baku

Setelah diperoleh semua biaya bahan baku yang terpakai, selanjutnya akan dihitung biaya bahan baku yang habis terpakai/kemasan dengan menggunakan rumus berikut : 
1 buah kemasan $=\frac{\text { Total biaya bahan baku/hari }}{\text { jumlah produksi } / \text { hari }}$

\subsubsection{Perhitungan biaya produksi/kemasan.}

Biaya produksi merupakan biaya yang dikeluarkan oleh Najmah Klappertaart untuk memproduksi Klappertaart. Untuk perhitungan biaya produksi/kemasan digunakan rumus sebagai berikut :

Biaya produksi/kemasan = biaya tenaga kerja/kemasan + biaya bahan baku/kemasan

dengan menggunakan persamaan (8), diperoleh biaya produksi/kemasan untuk klappertaart basah keju yaitu Rp. 3.216, klappertaart basah durian Rp. 3.244, klappertaart basah oreo Rp. 2.994 dan klappertaart basah original Rp 3.455. Sedangkan untuk klappertaart kering keju yaitu Rp. 18.111, klappertaart kering kismis Rp. 19.968 dan kering original Rp. 19.238.

\subsubsection{Perhitungan Penjualan (Margin yang diperoleh)}

Harga penjualan untuk klappertaart basah yaitu sebesarRp. 10.000/kemasan. Sedangkan untuk klappertaart kering yaitu sebesarRp. 30.000. Untuk menghitung laba yang didapatkan oleh Najmah Klappertaart digunakan rumus berikut :

laba keuntungan $=$ harga penjualan $/$ kemasan - biaya produksi $/$ kemasan

dengan menggunakan persamaan (9), diperoleh laba keuntungan untuk klappertaart basah keju yaitu Rp. 6.783, klappertaart basah durian Rp. 6.755, klappertaart basah oreo Rp. 7.005 dan klappertaart basah original Rp 6.544. Sedangkan untuk klappertaart kering keju yaitu Rp. 11.888, klappertaart kering kismis Rp. 10.031 dan kering original Rp. 10.761.

\subsubsection{Perumusan Masalah Goal programming}

a. Penentuan Variabel Keputusan

Variabel keputusan merupakan output yang akan dioptimalkan sehingga memenuhi kriteria sasaran dan kendala. Variabel keputusan untuk perencanaan produksi di Najmah Klappertaart adalah jumlah masing-masing jenis produk yang akan diproduksi, yaitu :

$\mathrm{X}_{1}=$ banyaknya jumlah produksi klappertart basah keju

$\mathrm{X}_{2}=$ banyaknya jumlah produksi klappertaart basah durian

$\mathrm{X}_{3}=$ banyaknya jumlah produksi klappertaart basah oreo

$\mathrm{X}_{4}=$ banyaknya jumlah produksi klappertaart basah original

$\mathrm{X}_{5}=$ banyaknya jumlah produksi klappertaart kering keju

$\mathrm{X}_{6}=$ banyaknya jumlah produksi klappertaart kering kismis 
$\mathrm{X}_{7}=$ banyaknya jumlah produksi klappertaart kering original

b. Menentukan fungsi kendala pemakaian bahan baku dan ketersediaan bahan baku

Penentuan fungsi kendala untuk pemakaian bahan baku dan ketersedian bahan baku, diperoleh dari banyaknya pemakaian bahan baku yang terpakai pada setiap kemasan klappertaart dan banyaknya persedian bahan baku dalam 1 hari.

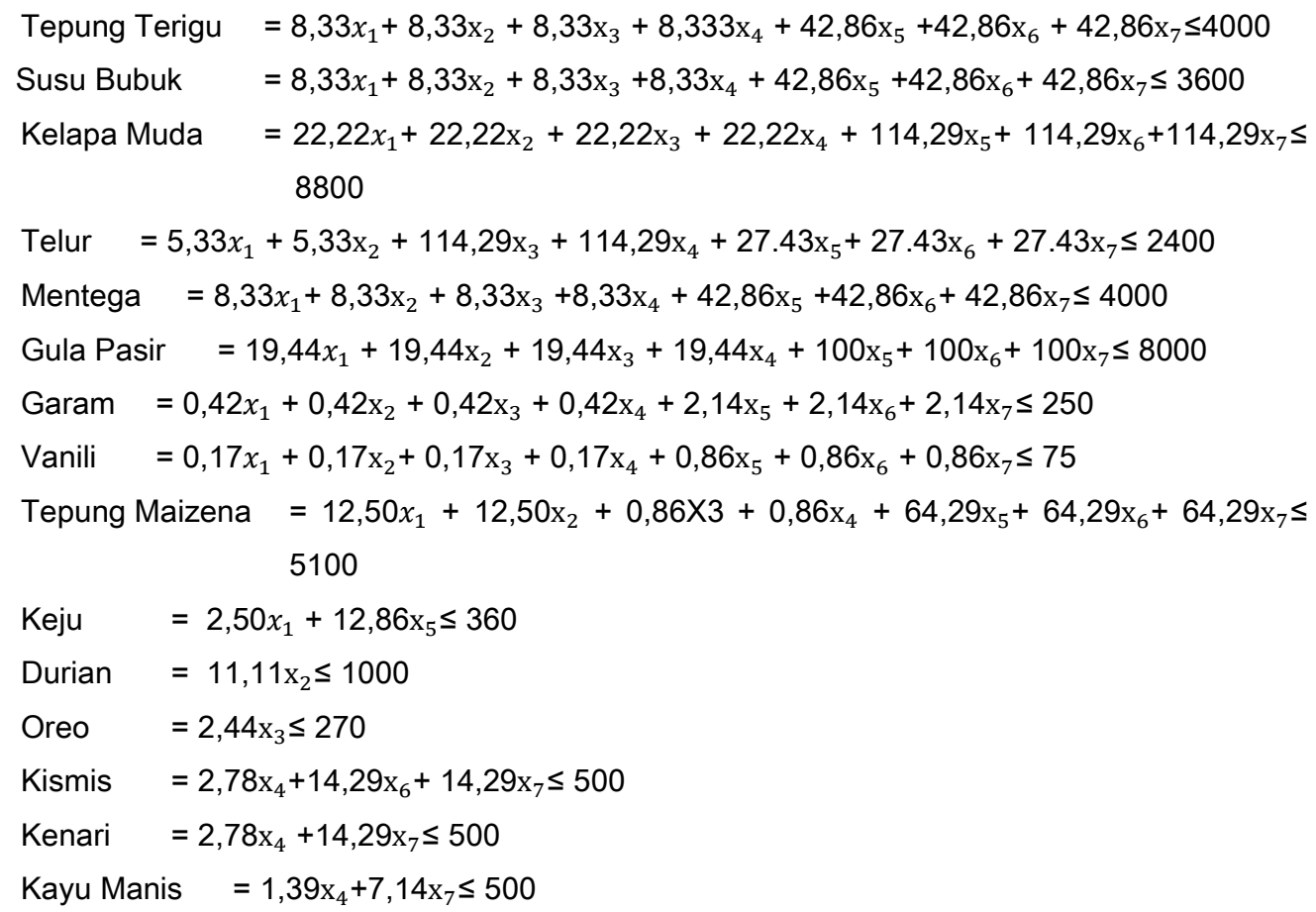

c. Kendala jumlah produksi

Kendala jumlah produksi merupakan asumsi dari penelitian. Bahwa jumlah produksi klappertaart dalam sehari paling sedikit 50 kemasan untuk klappertaart basah dan 5 kemasan/hari untuk klappertaart kering.

$\begin{array}{ll}\text { Klappertaart basah keju } & : x_{1} \geq 50 \\ \text { Klappertaart basah durian } & : x_{2} \geq 50 \\ \text { Klappertaart basah oreo } & : x_{3} \geq 50 \\ \text { Klappertaart basah original } & : x_{4} \geq 50 \\ \text { Klappertaart kering keju } & : x_{5} \geq 5 \\ \text { Klappertaart kering kismis } & : x_{6} \geq 5 \\ \text { Klappertaart kering original } & : x_{7} \geq 5\end{array}$


3.1.8. Menyatakan fungsi tujuan/sasaran

a. Memaksimalkan pendapatan

Adapun pendapatan penjualan dari hasil penjualan produk yang ingin dicapai agar maksimal yaitu diperoleh dari laba keuntungan. Fungsi tujuanya sebagai berikut :

Maksimasi $Z=6.783,64 x_{1}+6.755 .86 x_{2}+7.005 .86 x_{3}+6.564,47 x_{4}+11.888,86 x_{5}+$ $10.031,72 \mathrm{x}_{6}+10.761,72 \mathrm{x}_{7}$

b. Meminimumkan biaya produksi

Adapun biaya produksi yang ingin diminimalkan sehingga biaya yang keluar tidak terlalu banyak untuk proses setiap produknya sebagai berikut :

Minimasi $Z=3.216,36 \mathrm{x}_{1}+3.244,14 \mathrm{x}_{2}+2.994,14 \mathrm{x}_{3}+3.435,53 \mathrm{x}_{4}+18.111,14 \mathrm{x}_{5}+$ $19.968,28 \mathrm{x}_{6}+19.238,28 \mathrm{x}_{7}$

\subsubsection{Memformulasikan model Goal Programming}

Berdasarkan sasaran-sasaran yang ingin dicapai, maka formulasi untuk permasalahan Goal Programming adalah :

$$
\begin{aligned}
\operatorname{Min} Z=\boldsymbol{P}_{1}\left(d_{1}{ }^{-}\right. & \left.-d_{1}{ }^{+}\right)+\boldsymbol{P}_{2}\left(d_{2}{ }^{-}-d_{2}{ }^{+}\right)+\boldsymbol{P}_{\mathbf{3}}\left(d_{3}{ }^{-}-d_{3}{ }^{+}\right)+\boldsymbol{P}_{4}\left(d_{4}{ }^{-}-d_{4}{ }^{+}\right)+\boldsymbol{P}_{\mathbf{5}}\left(d_{5}{ }^{-}-d_{5}{ }^{+}\right) \\
& +\boldsymbol{P}_{\mathbf{6}}\left(d_{6}{ }^{-}-d_{6}{ }^{+}\right)+\boldsymbol{P}_{7}\left(d_{7}{ }^{-}-d_{7}{ }^{+}\right)+\boldsymbol{P}_{\mathbf{8}}\left(d_{8}{ }^{-}-d_{8}{ }^{+}\right)+\boldsymbol{P}_{\mathbf{9}}\left(d_{9}{ }^{-}-d_{9}{ }^{+}\right) \\
& +\boldsymbol{P}_{10}\left(d_{10}{ }^{-}-d_{10}{ }^{+}\right)+\boldsymbol{P}_{11}\left(d_{11}{ }^{-}-d_{11}{ }^{+}\right)+\boldsymbol{P}_{12}\left(d_{12}{ }^{-}-d_{12}{ }^{+}\right) \\
& +\boldsymbol{P}_{13}\left(d_{13}{ }^{-}-d_{13}{ }^{+}\right)+\boldsymbol{P}_{14}\left(d_{14}{ }^{-}-d_{14}{ }^{+}\right)+\boldsymbol{P}_{15}\left(d_{15}{ }^{-}-d_{15}{ }^{+}\right) \\
& +\boldsymbol{P}_{15}\left(d_{16}{ }^{-}-d_{16}{ }^{+}\right)+\boldsymbol{P}_{17}\left(d_{17}{ }^{-}-d_{17}{ }^{+}\right)+\boldsymbol{P}_{18}\left(d_{18}{ }^{-}-d_{18}{ }^{+}\right) \\
& +\boldsymbol{P}_{19}\left(d_{19}{ }^{-}-d_{19}{ }^{+}\right)+\boldsymbol{P}_{20}\left(d_{20}{ }^{-}-d_{20}{ }^{+}\right)+\boldsymbol{P}_{21}\left(d_{21}{ }^{-}-d_{21}{ }^{+}\right) \\
& +\boldsymbol{P}_{\mathbf{2 2}}\left(d_{22}{ }^{-}-d_{22}{ }^{+}\right)
\end{aligned}
$$

KendalaTujuan :

$$
\begin{aligned}
& 8,33 x_{1}+8,33 \mathrm{x}_{2}+8,33 \mathrm{x}_{3}+8,33 \mathrm{x}_{4}+42,86 \mathrm{x}_{5}+82,86 \mathrm{x}_{6}+42,86 \mathrm{x}_{7}+\mathrm{d}_{1}{ }^{-}-\mathrm{d}_{1}{ }^{+}=4000 \\
& 8,33 \mathrm{x}_{1}+8,33 \mathrm{x}_{2}+8,33 \mathrm{x}_{3}+8,33 \mathrm{x}_{4}+42,86 \mathrm{x}_{5}+82,86 \mathrm{x}_{6}+42,86 \mathrm{x}_{7}+\mathrm{d}_{2}{ }^{-}-\mathrm{d}_{2}{ }^{+}=3600 \\
& 22,22 \mathrm{x}_{1}+22,22 \mathrm{x}_{2}+22,22 \mathrm{x}_{3}+22,22 \mathrm{x}_{4}+114,29 \mathrm{x}_{5}+114,29 \mathrm{x}_{6}+114,29 \mathrm{x}_{7}+\mathrm{d}_{3}{ }^{-}-\mathrm{d}_{3}{ }^{+}=8800 \\
& 5,33 \mathrm{x}_{1}+5,33 \mathrm{x}_{2}+5,33 \mathrm{x}_{3}+5,33 \mathrm{x}_{4}+27,43 \mathrm{x}_{5}+27,43 \mathrm{x}_{6}+27.43 \mathrm{x}_{7}+\mathrm{d}_{4}{ }^{-}-\mathrm{d}_{4}{ }^{+}=2400 \\
& 8,33 \mathrm{x}_{1}+8,33 \mathrm{x}_{2}+8,33 \mathrm{x}_{3}+8,33 \mathrm{x}_{4}+42,86 \mathrm{x}_{5}+42,86 \mathrm{x}_{6}+42,86 \mathrm{x}_{7}+\mathrm{d}_{5}{ }^{-}-\mathrm{d}_{5}{ }^{+}=4000 \\
& 19,44 \mathrm{x}_{1}+19,44 \mathrm{x}_{2}+19,44 \mathrm{x}_{3}+19,44 \mathrm{x}_{4}+100 \mathrm{x}_{5}+100 \mathrm{x}_{6}+100 \mathrm{x}_{7}+\mathrm{d}_{6}{ }^{-}-\mathrm{d}_{6}{ }^{+}=8000 \\
& 0,42 x_{1}+0,42 \mathrm{x}_{2}+0,42 \mathrm{x}_{3}+0,42 \mathrm{x}_{4}+2,14 \mathrm{x}_{5}+2,14 \mathrm{x}_{6}+2,14 \mathrm{x}_{7}+\mathrm{d}_{7}{ }^{-}-\mathrm{d}_{7}{ }^{+}=250 \\
& 0,17 \mathrm{x}_{1}+0,17 \mathrm{x}_{2}+0,17 \mathrm{x}_{3}+0,17 \mathrm{x}_{4}+0,86 \mathrm{x}_{5}+0,86 \mathrm{x}_{6}+0,86 \mathrm{x}_{7}+\mathrm{d}_{8}{ }^{-}-\mathrm{d}_{8}{ }^{+}=75 \\
& 12,50 x_{1}+12,50 \mathrm{x}_{2}+12,50 \mathrm{x}_{3}+12,50 \mathrm{x}_{4}+64,23 \mathrm{x}_{5}+64,29 \mathrm{x}_{6}+64,29 \mathrm{x}_{7}+\mathrm{d}_{9}{ }^{-}-\mathrm{d}_{9}{ }^{+}=5100 \\
& 2,50 \mathrm{x}_{1}+12,86 \mathrm{x}_{5}+\mathrm{d}_{10}{ }^{-}-\mathrm{d}_{10}{ }^{+}=360 \\
& 11,11 \mathrm{x}_{2}+\mathrm{d}_{11}{ }^{-}-\mathrm{d}_{11}{ }^{+}=1000 \\
& 2,44 \mathrm{x}_{3}+\mathrm{d}_{12}{ }^{-}-\mathrm{d}_{12}{ }^{+}=270 \\
& 2,78 \mathrm{x}_{4}+14,29 \mathrm{x}_{6}+14,29 \mathrm{x}_{7}+\mathrm{d}_{13}{ }^{-}-\mathrm{d}_{13}{ }^{+}=500 \\
& 2,78 \mathrm{x}_{4}+14,29 \mathrm{x}_{7}+\mathrm{d}_{14}{ }^{-}-\mathrm{d}_{14}{ }^{+}=500 \\
& 1,39 \mathrm{x}_{4}+7,14 \mathrm{x}_{7}+\mathrm{d}_{15}{ }^{-}-\mathrm{d}_{15}{ }^{+}=500 \\
& \mathrm{x}_{1}+\mathrm{d}_{16}{ }^{-}-\mathrm{d}_{16}{ }^{+}=50
\end{aligned}
$$




$$
\begin{aligned}
& \mathrm{x}_{2}+\mathrm{d}_{17}{ }^{-}-\mathrm{d}_{17}{ }^{+}=50 \\
& \mathrm{x}_{3}+\mathrm{d}_{18}{ }^{-}-\mathrm{d}_{18}{ }^{+}=50 \\
& \mathrm{x}_{4}+\mathrm{d}_{19}{ }^{-}-\mathrm{d}_{19}{ }^{+}=50 \\
& \mathrm{x}_{5}+\mathrm{d}_{20}{ }^{-}-\mathrm{d}_{20}{ }^{+}=5 \\
& \mathrm{x}_{6}+\mathrm{d}_{21}{ }^{-}-\mathrm{d}_{21}{ }^{+}=5 \\
& \mathrm{x}_{7}+\mathrm{d}_{22}{ }^{-}-\mathrm{d}_{22}{ }^{+}=5
\end{aligned}
$$

Kendala non negatif

$\mathrm{X}_{1}, \mathrm{X}_{2}, \mathrm{X}_{3}, \mathrm{X}_{4}, \mathrm{X}_{5}, \mathrm{X}_{6}, \mathrm{X}_{7}, \mathrm{~d}_{1}^{-}, \mathrm{d}_{1}^{+}, \mathrm{d}_{2}^{-}, \mathrm{d}_{2}^{+}, \mathrm{d}_{3}^{-}, \mathrm{d}_{3}^{+}, \mathrm{d}_{4}^{-}, \mathrm{d}_{4}^{+}, \mathrm{d}_{5}^{-}, \mathrm{d}_{5}^{+}, \mathrm{d}_{6}^{-}, \mathrm{d}_{6}^{+}, \mathrm{d}_{7}^{-}, \mathrm{d}_{7}^{+}, \mathrm{d}_{8}^{-}, \mathrm{d}_{8}^{+}$, $\mathrm{d}_{9}^{-}, \mathrm{d}_{9}^{+}, \mathrm{d}_{10}^{-}, \mathrm{d}_{10}^{+}, \mathrm{d}_{11}^{-}, \mathrm{d}_{11}^{+}, \mathrm{d}_{12}^{-}, \mathrm{d}_{12}^{+}, \mathrm{d}_{13}^{-}, \mathrm{d}_{13}^{+}, \mathrm{d}_{14}^{-}, \mathrm{d}_{14}^{+}, \mathrm{d}_{15}^{-}, \mathrm{d}_{15}^{+}, \mathrm{d}_{16}^{-}, \mathrm{d}_{16}^{+}, \mathrm{d}_{17}^{-}, \mathrm{d}_{17}^{+}, \mathrm{d}_{18}^{-}$, $\mathrm{d}_{18}^{+}, \mathrm{d}_{19}^{-}, \mathrm{d}_{19}^{+}, \mathrm{d}_{20}^{-}, \mathrm{d}_{20}^{+}, \mathrm{d}_{21}^{-}, \mathrm{d}_{21}^{+}, \mathrm{d}_{22}^{-}, \mathrm{d}_{22}^{+} \geq 0$

\subsubsection{Penyelesaian model matematis Goal Programming.}

Menurut Yuwono B. (2007), langkah - langkah untuk menyelesaikan model Goal Programming yaitu

a. Membentuk tabel simpleks awal.

Memasukan nilai-nilai fungsi kendala kedalam tabel simpleks.

b. Pilih kolom kunci dimana $C_{j}-Z_{j}$ memiliki nilai negatif terbesar.

c. Pilih baris kunci yang berpedoman pada $b_{i} / a_{i j}$ dengan rasio terkecil.

d. Mencari sistem kanonikal yaitu sistem dimana nilai elemen pivot bernilai 1 dan elemen lain bernilai nol dengan cara menggunakan Operasi Baris Elementer (OBE), Dengan demikian diperoleh tabel simpleks iterasi i.

e. Pemeriksaaan optimalitas, yaitu melihat apakah solusi sudah layak atau tidak. Solusi dikatakan layak bila variabel adalah positif atau nol. $\left(C_{j}-Z_{j} \geq 0\right)$.

\subsubsection{Penyelesaian masalah matematis Goal Programming.}

Pada iterasi 1 nilai pada baris $C_{j}-Z_{j}<0$, sehingga dikatakan solusi belum optimal. Sehingga perhitungan akan dilanjutkan sampai mendapatkan nilai yang layak atau optimal. $\left(C_{j}-Z_{j} \geq 0\right)$. Penyelesaian perhitungan Goal Programming akan dibantu dengan menggunakan Software WinQSB

\subsubsection{Penyelesaian masalah Goal Programming dengan aplikasi WinQSB}

WinQSB adalah system interaktif untuk membantu pengambilan keputusan yang berisi alat yang berguna untuk memecahkan berbagai jenis masalah dalam bidang riset operasi. 
a. Memasukan nilai fungsi kendala dan tujan kedalam tabel

\begin{tabular}{|c|c|c|c|c|c|c|c|c|c|}
\hline Variable --> & $x 1$ & $x 2$ & $\times 3$ & $x_{4}$ & $\times 5$ & $x 6$ & $x 7$ & Direction & R. H. S. \\
\hline Max:G1 & 6783.64 & 6755.86 & 7005.86 & 6564.47 & 11888.86 & 10031.72 & 10761.72 & & \\
\hline Min:62 & 3216.36 & 3244.14 & 2994.14 & 3435.53 & 18111.14 & 19968.28 & 19238.28 & & \\
\hline Tepung & 8.33 & 8.33 & 8.33 & 8.33 & 42.86 & 42.86 & 42.86 & $<=$ & 4000 \\
\hline Susu & 8.33 & 8.33 & 8.33 & 8.33 & 42.86 & 42.86 & 42.86 & $<=$ & 3600 \\
\hline kelapa Muda & 22.22 & 22.22 & 22.22 & 22.22 & 114.29 & 114.29 & 114.29 & $<=$ & 8800 \\
\hline Telur & 5.33 & 5.33 & 5.33 & 5.33 & 27.43 & 27.43 & 27.43 & $<=$ & 2400 \\
\hline Mentega & 8.33 & 8.33 & 8.33 & 8.33 & 42.86 & 42.86 & 42.86 & $<=$ & 4000 \\
\hline Gula Pasir & 19.44 & 19.44 & 19.44 & 19.44 & 100.00 & 100.00 & 100.00 & $<=$ & 8000 \\
\hline Garam & 0.42 & 0.42 & 0.42 & 0.42 & 2.14 & 2.14 & 2.14 & $<=$ & 250 \\
\hline Vanili & 0.17 & 0.17 & 0.17 & 0.17 & 0.86 & 0.86 & 0.86 & $<=$ & 75 \\
\hline Tepung & 12.50 & 12.50 & 12.50 & 12.50 & 64.29 & 64.29 & 64.29 & $<=$ & 5100 \\
\hline Keju & 2.50 & o & $\mathbf{0}$ & $\mathbf{0}$ & 12.86 & $\mathbf{0}$ & o & $<=$ & 360 \\
\hline Durian & o & 11.11 & 0 & 0 & o & $\mathbf{0}$ & o & $\Leftrightarrow$ & 1000 \\
\hline Oreo & $\mathbf{0}$ & $\mathbf{0}$ & 2.44 & $\mathbf{0}$ & $\mathbf{0}$ & $\mathbf{0}$ & $\mathbf{0}$ & $<=$ & 270 \\
\hline kismis & $\mathbf{0}$ & $\mathbf{0}$ & $\mathbf{0}$ & 2.78 & o & 14.29 & 14.29 & $<=$ & 500 \\
\hline kenari & $\mathbf{0}$ & $\mathbf{0}$ & $\mathbf{0}$ & 2.78 & o & $\mathbf{0}$ & 14.29 & $<=$ & 500 \\
\hline Kayu Manis & $\mathbf{0}$ & $\mathbf{0}$ & $\mathbf{0}$ & 1.39 & $\mathbf{0}$ & $\mathbf{0}$ & 7.14 & $<=$ & 500 \\
\hline Basah keju & 1 & o & o & $\mathbf{0}$ & o & o & $\mathbf{0}$ & \rangle$=$ & 50 \\
\hline Basah & o & 1 & $\mathbf{0}$ & o & o & $\mathbf{0}$ & $\mathbf{0}$ & \rangle$=$ & 50 \\
\hline Basah oreo & o & o & 1 & $\mathbf{0}$ & o & $\mathbf{0}$ & $\mathbf{0}$ & \rangle$=$ & 50 \\
\hline Basah & $\mathbf{0}$ & $\mathbf{0}$ & $\mathbf{0}$ & 1 & o & $\mathbf{0}$ & $\mathbf{0}$ & $>=$ & 50 \\
\hline Kering keju & $\mathbf{0}$ & $\mathbf{0}$ & 0 & $\mathbf{0}$ & 1 & o & $\mathbf{0}$ & \rangle$=$ & 5 \\
\hline Kering & $\mathbf{0}$ & $\mathbf{0}$ & o & $\mathbf{0}$ & o & 1 & 0 & \rangle$=$ & 5 \\
\hline Kering & $\mathbf{0}$ & $\mathbf{0}$ & $\mathbf{0}$ & o & o & o & 1 & $>=$ & 5 \\
\hline LowerBound & $\mathbf{0}$ & $\mathbf{0}$ & o & $\mathbf{0}$ & $\mathbf{0}$ & $\mathbf{0}$ & $\mathbf{0}$ & & \\
\hline UpperBound & M & M & M & M & M & M & M & & \\
\hline VariableType & Continuous & Continuous & Continuous & Continuous & Continuous & Continuous & Continuous & & \\
\hline
\end{tabular}

Gambar 1 : Pengisian data pada masalah Goal Programming

b. Tampilan iteras iterakhir

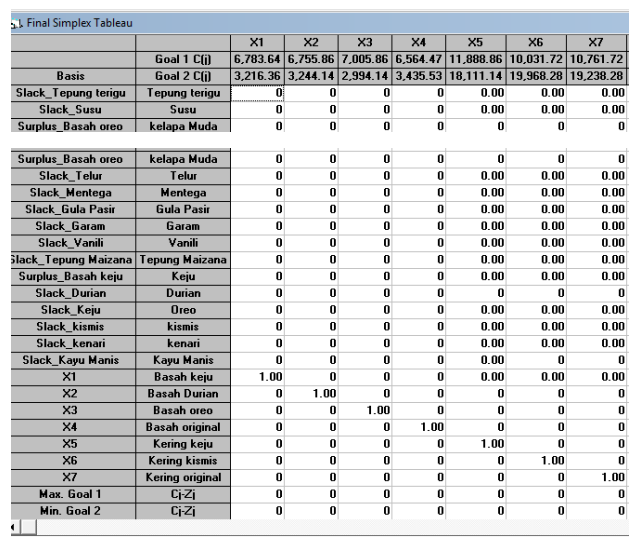

Gambar 2 : Pengisian data pada masalah Goal Programming

Pada gambar 2, terlihat bahwa $C_{j}-Z_{j} \geq 0$, sehingga dikatakan solusi telah optimal. 
C. Tampilan kombinasi Goal Programming

\begin{tabular}{|c|c|c|c|c|c|c|c|c|c|}
\hline & $\begin{array}{l}\text { Goal } \\
\text { Level }\end{array}$ & \begin{tabular}{|l|} 
Decision \\
Variable
\end{tabular} & $\begin{array}{c}\text { Solution } \\
\text { Value }\end{array}$ & $\begin{array}{c}\text { Unit Cost or } \\
\text { Profit c(i) }\end{array}$ & $\begin{array}{c}\begin{array}{c}\text { Total } \\
\text { Contribution }\end{array} \\
\end{array}$ & $\begin{array}{c}\text { Reduced } \\
\text { Cost }\end{array}$ & $\begin{array}{c}\text { Allowable } \\
\text { Min. c(i) }\end{array}$ & $\begin{array}{l}\text { Allowable } \\
\text { Max. c(i] }\end{array}$ & \\
\hline 1 & G1 & $\mathrm{x} 1$ & 108.23 & 6.783 .64 & \begin{tabular}{|l|}
734.196 .19 \\
\end{tabular} & $\mathbf{0}$ & 6.755 .86 & $7,005.86$ & \\
\hline 2 & G1 & $x 2$ & 50.00 & 6.755 .86 & 337.793 .00 & $\mathbf{0}$ & $-M$ & 6.783.64 & \\
\hline 3 & G1 & $x_{3}$ & 110.66 & $7,005.86$ & 775.238 .63 & $\mathbf{0}$ & 6.783.64 & $M$ & \\
\hline 4 & G1 & $x_{4}$ & 50.00 & 6.564.47 & 328.223 .50 & $\mathbf{0}$ & $-M$ & 6.783 .64 & \\
\hline 5 & G1 & $\times 5$ & 5.00 & $11,888.86$ & 59,444.30 & 0 & $-M$ & $34,892.09$ & \\
\hline 6 & G1 & $\times 6$ & 5.00 & $10,031.72$ & 50.158 .60 & $\mathbf{0}$ & $-M$ & $34,892.09$ & \\
\hline 7 & G1 & $x 7$ & 5.00 & 10.761 .72 & $53,808.60$ & $\mathbf{0}$ & $-M$ & $34,892.09$ & \\
\hline 8 & G2 & $\mathrm{x} 1$ & 108.23 & 3.216 .36 & 348.108 .00 & $\mathbf{0}$ & $-M$ & M & \\
\hline 9 & G2 & $\times 2$ & 50.00 & 3.244 .14 & $162,207.00$ & $\mathbf{0}$ & $-M$ & M & \\
\hline 10 & 62 & X3 & 110.66 & $2,994.14$ & $331,318.75$ & $\mathbf{0}$ & $-M$ & M & \\
\hline 11 & G2 & $x_{4}$ & 50.00 & 3.435 .53 & $171,776.50$ & $\mathbf{0}$ & $-M$ & M & \\
\hline 12 & G2 & $\times 5$ & 5.00 & 18.111.14 & 90.555 .70 & $\mathbf{0}$ & $-M$ & M & \\
\hline 13 & G2 & $\times 6$ & 5.00 & 19.968.28 & 99.841 .40 & $\mathbf{0}$ & $-M$ & M & \\
\hline \multirow[t]{4}{*}{14} & 62 & $x 7$ & 5.00 & 19.238 .28 & 96.191 .40 & $\mathbf{0}$ & $-M$ & M & \\
\hline & G1 & Goal & Value & (Max. $]=$ & $2,338.862 .50$ & & & & \\
\hline & G2 & Goal & Value & {$[$ Min. $]=$} & $1,299.998 .75$ & & & & \\
\hline & Constraint & $\begin{array}{c}\text { Left Hand } \\
\text { Side }\end{array}$ & Direction & $\begin{array}{l}\text { Right Hand } \\
\text { Side }\end{array}$ & $\begin{array}{c}\text { Slack } \\
\text { or Surplus }\end{array}$ & $\begin{array}{l}\text { Allowable } \\
\text { Min. RHS }\end{array}$ & $\begin{array}{l}\text { Allowable } \\
\text { Max. RHS }\end{array}$ & $\begin{array}{c}\text { ShadowPrice } \\
\text { Goal } 1\end{array}$ & $\begin{array}{c}\text { ShadowPrice } \\
\text { Goal } 2\end{array}$ \\
\hline 1 & Tepung terigu & $3,299.22$ & $<=$ & $4,000.00$ & 700.78 & 3.299 .22 & M & o & 0 \\
\hline 2 & chen & 220020 & I- & 2 Enก กn & 20078 & 220920 & 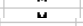 & n & $\mathrm{n}$ \\
\hline 2 & Susu & 3.299 .22 & $<=$ & $3,600.00$ & 300.78 & $3,299.22$ & M & 0 & 0 \\
\hline 3 & kelapa Muda & $8,800.00$ & $<=$ & 8.800 .00 & 0 & $7,506.12$ & 9,023.30 & 305.29 & 144.75 \\
\hline 4 & Telur & $2,111.11$ & $<=$ & 2.400 .00 & 288.89 & 2,111.11 & M & 0 & 0 \\
\hline 5 & Mentega & $3,299.22$ & $<=$ & $4,000.00$ & 700.78 & \begin{tabular}{|l|}
$3,299.22$ \\
\end{tabular} & M & 0 & 0 \\
\hline 6 & Gula Pasir & 7.699.15 & $<=$ & 8.000 .00 & 300.85 & $7,699.15$ & M & 0 & $\mathbf{0}$ \\
\hline 7 & Garam & 166.03 & $<=$ & 250.00 & 83.97 & 166.03 & M & 0 & 0 \\
\hline 8 & Vanili & 67.11 & $<=$ & 75.00 & 7.89 & 67.11 & M & $\mathbf{0}$ & $\mathbf{0}$ \\
\hline 9 & Tepung Maizana & 4.950 .43 & $<=$ & 5.100 .00 & 149.57 & $4,950.43$ & M & $\mathbf{0}$ & $\mathbf{0}$ \\
\hline 10 & Keju & 334.88 & $<=$ & 360.00 & 25.12 & 334.88 & M & 0.00 & 0.00 \\
\hline 11 & Durian & 555.50 & $<=$ & $1,000.00$ & 444.50 & 555.50 & M & $\mathbf{0}$ & $\mathbf{0}$ \\
\hline 12 & Oreo & 270.00 & $<=$ & 270.00 & 0 & 245.48 & 412.08 & 91.07 & -91.07 \\
\hline 13 & kismis & 281.90 & $<=$ & 500.00 & 218.10 & 281.90 & M & $\mathbf{0}$ & $\mathbf{0}$ \\
\hline 14 & kenari & 210.45 & $<=$ & 500.00 & 289.55 & 210.45 & M & $\mathbf{0}$ & $\mathbf{0}$ \\
\hline 15 & Kayu Manis & 105.20 & $<=$ & 500.00 & 394.80 & 105.20 & M & $\mathbf{0}$ & $\mathbf{0}$ \\
\hline 16 & Basah keju & 108.23 & \rangle$=$ & 50.00 & 58.23 & $-M$ & 108.23 & $\mathbf{0}$ & o \\
\hline 17 & Basah Durian & 50.00 & \rangle$=$ & 50.00 & $\mathbf{0}$ & 39.95 & 90.01 & -27.78 & 27.78 \\
\hline 18 & Kering original & 110.66 & \rangle$=$ & 50.00 & 60.66 & $-M$ & 110.66 & 0 & 0 \\
\hline 19 & kering keju & 50.00 & \rangle$=$ & 50.00 & 0 & 39.95 & 108.23 & -219.17 & 219.17 \\
\hline 20 & Basah original & 5.00 & \rangle$=$ & 5.00 & 0 & $\mathbf{0}$ & 16.32 & $-23,003.23$ & $1,567.58$ \\
\hline 21 & basah oreo & 5.00 & $>=$ & 5.00 & $\mathbf{0}$ & 3.05 & 16.32 & $-24,860.37$ & 3.424 .72 \\
\hline 22 & kering kismis & 5.00 & $\lambda=$ & 5.00 & 0 & 3.05 & 16.32 & $-24,130.37$ & $2,694.72$ \\
\hline
\end{tabular}

Gambar 3 : kombinasi Goal Programming dari pegolahan data

d. Tampilan jumlah iterasi

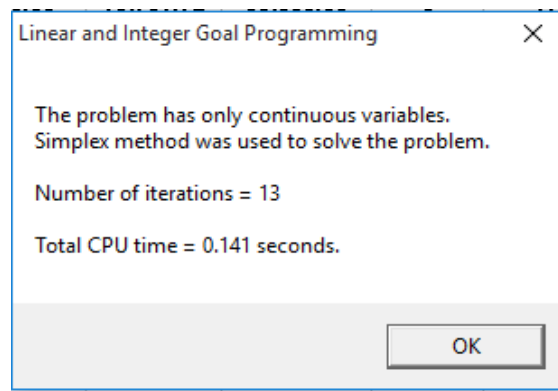

Gambar 4 : jumlah iterasi pada Goal Programming

\subsection{Pembahasan}

Dari pengolahan data dengan menggunakan program WINQSB (gambar 3), didapatkan nilai optimal maksimal pendapatan laba penjualan sebesar Rp. 2.338.862/hari. Sedangkan nilai optimal minimasi biaya produksi sebesar Rp. 1.299.998/hari dengan 
ketentuan memproduksi klappertaart basah keju sebanyak 108 kemasan/hari, Klappertaart basah durian 50 kemasan/hari, Klappertaart basah oreo 110 kemasan/hari, Klappertaart basah original 50 kemasan/hari, klappertaart kering keju 5 kemasan/hari, Klappertaart kering kismis 5 kemasan/hari dan klappertaart kering original 5 kemasan/hari. Jika dari jumlah produksi yang didapatkan disubtitusikan kedalam fungsi tujuan, maka diperoleh nilai sebagai berikut.

$\mathrm{X}_{1}=108$ (jumlah produksi klappertart basah keju)

$\mathrm{X}_{2}=50$ (jumlah produksi klappertaart basah durian)

$\mathrm{X}_{3}=110$ (jumlah produksi klappertaart basah oreo)

$\mathrm{X}_{4}=50$ (jumlah produksi klappertaart basah original)

$\mathrm{X}_{5}=5$ (jumlah produksi klappertaart kering keju)

$\mathrm{X}_{6}=5$ (jumlah produksi klappertaart kering kismis)

$\mathrm{X}_{7}=5$ (jumlah produksi klappertaart kering original)

Maksimasi keuntungan $Z=2.332 .705$

Minimasi biayaZ $=1.297 .294$

\section{KESIMPULAN}

Berdasarkan perhitungan yang telah dilakukan dapat di ambil kesimpulan sebagai berikut :

a. Najmah Klappertaart memproduksi Klappertaart sebanyak 332 kemasan/hari. Hasil produksi ini meningkat dari hasil produksi sebelumnya sebanyak 309 kemasan/hari, dengan ketentuan memproduksi Klappertaart basah keju sebanyak 118 kemasan/hari, Klappertaart basah durian 84 kemasan/hari, Klappertaart basah oreo 110 kemasan/hari, Klappertaart basah original 5 kemasan/hari, Klappertaart kering keju 5 kemasan/hari, Klappertaart kering kismis 5 kemasan/hari dan Klappertaart kering original 5 kemasan/hari, , Sehingga menghasilkan pendapatan laba penjualan sebesar Rp. 2.347.754 meningkat sebesar Rp. 167.071 dari pendapatan laba sebelumnya Rp. 2.180.683.

b. Dengan menggunakan metode Goal Programming minimasi pengeluaran biaya produksi sebesar Rp. 1.291.106 menurun sebesar Rp. 38.210 dari biaya produksi sebelumnya Rp. 1.329.316. 


\section{DAFTAR PUSTAKA}

[1] Harini., 2014. Peningkatan Kapasitas Produksi Peti Alumunium Untuk Memenuhi Kebutuhan Permintaan Melalui Optimalisasi Jadwal Induk Produksi Di Pt.BJK, Jurnal IImiah WIDYA, Agustus - Oktober, Volume 2., No. 3.

[2] Marpaung, J., 2009. Perencanaan Produksi yang Optimal dengan Pendekatan Goal Programming di PT. Gold Koin Indonesia, Fakultas Teknik Universitas Sumatera Utara.

[3] Siswanto, 2007. Operation Research, Jakarta :Erlangga.

[4] Yuwono, B., 2007. Bahan Kuliah Riset Operation, Fakultas Teknologi Industri Universitas Pembangunan Nasional, Yogyakarta. 